Illustrated by the Experience of the Netherlands Economy", by Prof. J. B. D. Derkson, to make available to English readers some of the basic researches behind developments in economic planning in Holland, and it has also provided a meeting-place for the discussion of technical aspects of such problems between official representatives from Norway and Sweden and those engaged in similar work in Britain.

The immense tasks which face the advisers of Government call for a wealth of factual, quantitative information about the British economy and its development in the recent past which cannot be supplied entirely from official sources, and the contribution of the Institute in this field is of increasing importance. Of particular significance in this connexion, through its bearing on the structure and productivity of the national economy, is the inquiry on the "National Expenditure, Output and Income, 1920-38", which continued to be directed by Mr. Richard Stone. A first volume containing the results of the investigation into consumers' expenditure is already in the hands of the printers : as is a report on "Productivity, Prices and Distribution in Selected British Industries". A second report from the same investigation, "International Comparisons of Productivity in British and American Manufacturing Industry", is now being finally prepared for publication, while during the year work was started on the distribution inquiry with the aim at the first stage of building up a factual picture of the channels by which consumer goods passed from the manufacturer to the public in the immediate pre-war period. The second stage of the inquiry is concerned with the more difficult problem of the functions, stock turn, and cost and profit experience of different types of wholesaler and retailer. Late in 1945 a building inquiry was commenced, under Mr. I. Bowen, covering the structure and efficiency of the building industry, housing demand and the building cycle, and economic problems arising from new building techniques. Main attention is being given to the first topic, and it is hoped that a report on this part of the programme will be completed during 1947 .

The work on capital formation and public authority expenditure has continued, attention so far having been concentrated on the current and capital expenditure of local authorities. The inquiry into disease mortality and its changing distribution has issued in a draft report "The Social Geography of Mortality in England and Wales, 1911-38"; but Dr. Kuczynski's study of post-war population problems has been suspended while the Royal Commission on Population is in session. The inquiry into advertising has been completed, and a report on "Statistics of Advertising" is to be published later. Miss P. M. Deane completed her Occasional Paper, "The Measurement of Colonial National Incomes: an Experiment", before taking up her field experiments as a Colonial research fellow in Africa. A joint exploratory committee with representatives of the Institute of Chartered Accountants has considered the field of work in which accountants and economists have a common interest, and it is hoped to publish later an agreed statement of its findings. Senior research fellowships were awarded during the year, under the scheme described in last year's report, to Mr. E. J. M. Buckatzsch for an inquiry into "Factors Affecting Income per Head in Towns and Areas in England and Wales, 1929-1939", to Miss K. Liepmann, for an inquiry into "The Extent and Composition of Labour Markets in Selected Areas in the South West", and Mr. H. G. Schenk's part-time fellowship has been extended to enable him to complete his inquiry into "European Romanticism and the Social Revolution, 1790-1830". The Register of Research in the Social Sciences for 1940 is being distributed as a confidential document. New Institute publications during the year are listed in the report.

\section{SALMON MIGRATION AT SEA}

7 HE Buckland Foundation Lecture was given by J. W. Menzies at the University of Liverpool, on May 28, Prof. J. H. Orton presiding. Taking for his subject "The Migrations of Salmon in the Sea", Mr. Menzies summarized the information learned from the experiments of marking salmon in Scottish, Norwegian, Baltic, and Canadian haunts, and suggested that European and Canadian salmon have a common feeding ground in the North Atlantic near Iceland, where a new marking station will probably be opened under international co-operation in a few years time. The only area where Salmo salar has been traced from the river of origin to its feeding ground in the sea and then back to the river as adult fish is the Baltic, where Swedish marking experiments showed that smolts left the northern Swedish and Finnish rivers in spring when only 5 in. long and reached the southern Baltic, 600-800 miles away, in October and November, when they weighed just over a pound after feeding; but they did not show evidence of passing out of this belt into the North Sea. Salmon apparently do not feed in the North Sea, or The Minch of western Scotland, or they would have been caught more often in the herring nets. The Swedish salmon feed in the southern Baltic for possibly up to two or three years before returning to their native rivers.

Salmon marked in the Gulf of St. Lawrence, and off the shores of Scotland and Norway, have shown two types of movements. In one they have been recovered after they have nearly completed their journey home again, when they remain off the river until a flood induces them to ascend. They cease feeding once they reach the coast, and if a drought keeps them there some weeks or months, they lose weight, a 15 -lb. fish losing $2-3 \mathrm{lb}$. in a little more than two months while waiting to ascend the river; a 15-lb. fish lost $4 \mathrm{lb}$. in 67 days; a 12-lb. fish lost $2 \mathrm{lb}$. in two months. Only five marked fish were recovered more than ten miles from Thurso Bay, and marking showed a similar restricted movement in the inner Moray Firth; only six out of more than 400 strayed outside the outer limits of the Firth, and there were similar results from Canada and Norway.

Other salmon, particularly those marked off southwest Newfoundland, western Scotland and western Norway, made long journeys to the place of capture, the record being a St. Lawrence fish caught as a clean fish in sea nets 2,000 miles away up the Labrador coast, while from near the north of Norway an easterly migration has been traced to the River Petchora, the easterly limit in the distribution of Salmo salar. In both Canada and Scotland these long journeys have often been four or six hundred miles, and on the Norwegian coast 1,600 miles to the White Sea. Marked salmon have travelled between Scotland and Norway, but not across the Atlantic, so far as recoveries show; but all these fish seem to be going back to the river from which they came as smolts. 
Marking not only indicates the length of migration, but also the speed, and the longer the migration the faster appears to be the speed, especially with Norwegian records, one of which was recovered 680 miles away in a little more than ten days, a speed of 62 miles per day. Adult salmon in the sea travel at a minimum rate of between ten and twenty-five miles a day.

Mr. Menzies suggested that the cause of the very poor salmon season of 1945 in Britain probably lay in feeding conditions at sea, not in fresh-water rivers, because in Iceland, Norway and Canada this was also a bad season. When swimming near the coast, salmon travel within $7 \mathrm{ft}$. of the surface; but although herring and sand-eels have been found in them, very little is known of their diet in the sea, and those caught near the shore were almost invariably empty.

\section{FORTHCOMING EVENTS}

(Meeting marked with an asterisk * is open to the public)

Monday, July 7-Wednesday, July 9

UNIVERSITY OF BRISTOY (at the H. H. Wills Physical Laboratory, Royal Fort, Bristol), at 9.30 a.m.; and 2.45 p.m. each day.-Conference on "The Strength of Solids".

Monday, July 7-Thursday, July 10

Royal SocieTy, GaSsiot SUb-Commrtree B (at Burlington House. Piccadilly, London, W.1).- Conference on the "Emission Spectra of the Night'sky and Auroræ."

Monday, July 7

At 11 a.m.-Prof. S. Chapman, F.R.S.: Opening Address.

Monday, July 7-Saturday, July 12

Chemical Society, Societr of Chemical Industry and Royai INSTITUTE OF CHEMISTRY, EDINBURGH and EAST OF SCOTLAND SECTIONS (at The University, St. Andrews). - Symposium on "Coal, Petroleum and their Newer Derivatives".

\section{Tuesday, July 8}

UNIVERSITY OF LONDON (at the London School of Hygiene and Tropical Medicine, Keppel Street, London, W.C.1), at 5.15 p.m.Dr. D. Rittenberg (Columbia University): "The Application of the

Wednesday, July 9-Saturday, July 12

SOCIETY FOR APPLIED BACTERIOLOGY (at Reading).-Annual General Meeting and Paper Reading Conference.

Wednesday, July 9

At 8 p.m. (at St. Andrews Hall).--Annual General Meeting. Thursday, July 10

"At 10 a.m. (in the Zoology Lecture Theatre).-Symposium on "Water Bacteriology"; at 2.15 p.m.-Paper Reading Conference. Friday, July II

At 10 a.m.-Paper Reading Conference.

Thursday, July 10-Saturday, July 12

Institute of Physics, Manchester and District BRanch (in the Physics Department, The University, Manchester).-Conference on "Applications, of

\section{APPOINTMENTS VACANT}

AppliCATIONS are invited for the following appointments on or before the dates mentioned :

LECTORER IN TEXTILE TECHNOLOGY, and a LECTORER IN MATHEMATICS-The Registrar, College of 'Technology and Commerce, The Newarke, Leicester (July 12).

SENIOR ASSISTANT (with a good Honours degree) IN THE DEPARTMENT OF CHEMISTRY, a LECTURER IN PHARMACY, a LECTURER (with a good Honours degree or its equivalent) IN MATHEMATICS, SENIOR ASSISTANTS (3) IN (a) DESIGN SECTION, (b) PRODUCTION ENGINEERING
SECTION, (c) for RESEARCH AND FXPERIMENTAL WORK, and LECTURERS (2) for $(a)$ DESIGN SECTION, $(b)$ PRODUCTION ENGINEERINe SECTION, in the Department of Mechanical Engineering, LECTURERS (2) in ELECTRICAL ENGINEERING up to Higher National Certificate standard, and LECTURERS (2) in (a) CARPENTRY AND JOINERY, (b) PLUMBING AND SANITARY ENGINEERING, in the Department of Building and Structural Engineering-The Principal, Central Technical College, Suffolk Street, Birmingham 1 (July 12).

LECTURER IN ZOOLOGY AND CHEMISTRY-The Registrar, Merchant Venturers' Technical College, Bristol (July 12).

Lecturer IN Physics-The Clerk to the Governing Body, Battersea Polytechnic, Battersea, London, S.W.11 (July 12).
LECTURER IN CHEMISTRY-The Clerk to the Governors, South-East Essex Technical College, Longbridge Road, Dagenham (July 14). LECTURER IN MATHEMATICS in the United College-The Secretary, The University, St. Andrews (July 15).

LECTURER IN GEOLOGY (Petrology and Mineralogy) in University College, Dundee-The Secretary, The University, St. Andrews (July 15). LECTURER IN ZOOLOGY to take charge of the Gatty Marine Laboratory-The Secretary, The University, St. Andrews (July 15).

LECTURER IN PHYSIOS, and a LEOTURER IN CIVII AND MECHANICAL ENGINEERINa-The Clerk to the Governors, Woolwich Polytechnic, Woolwich, London, S.E.18 (July 19).

Leoturer, and an Assistant Lectorer, in Physics-The Secretary, King's College, Strand, London, W.C.2 (July 21)

ADVISER in AGRIOULTURAL ECONOMICS, a SENIOR AGriculturau ECONOMIST, and an AsSISTANT AGRICULTURAL ECONOMIST-The Registrar, The University, Manchester 13 (July 26).

LECTURER IN THE TRCHNICAL DEPARTMEN', for City and Guilds Telecommunications up to Grade 5-The Technical Officer, University College, Southampton (July 26).

LECTURER (Grade II) Or ASSISTANT LeCTURER (Grade III) IN PHYsICS-The Registrar, University College, Southampton (July 26). LECTURER IN PHILOSOPHY in the University of the Witwatersrand, Johannesburg-The Secretary, Universities Bureau of the British Empire, 8 Park Street, London, W.1 (July 30).

DAIRY OFFICER IN THE DEPARTMENT OF AGRICULTURE AND LANDS, Southern Rhodesia-The Secretary, Office of the High Commissioner for Southern Rhodesia, Rhodesia House, 429 Strand, London, W.C.2 (July 31).

Statistician in the office of the Town Clerk-The Town Clerk, Town Clerk's Office, Room 30B, Council House, Birmingham 1, endorsed 'Central Statistical Officer' (July 31).

ZoologisTs (4) with special experience of taxonomic work on (a) mammals, (b) fishes, (c) arachnida, and (d) mollusca, and ENToMOLOGISTS (4) with special experience of taxonomic work, at the British 6 Burlington Gardens, London, W.1, quoting No. 1936 (July 31).

Burlington Gardens, London, W.1, quoting No. 1936 (July 31).
UNIVERSITY LECTURER IN PHYSICS--The Secretary of the Appointments Committee, Faculty of Physics and Chemistry, Chemical Laboratory, Pembroke Street, Cambridge (July 31).

LECTURER IN PATHOLOGY-The Registrar, The University, Sheffield (July 31).

DIRECTOR OF RESEARCH for the development of Rheumatism Treatment and Research, and a RESEARCH FELLOW IN THE SURGER F RHECMATISM-The Registrar, The University, Leeds (July 31). Sort BIOCHEMIST, a PHYSICAL CHEMIST with experience in a colloid
laboratory or used to X-ray technique, a PHYSICAL CHEMIST with experience in spectroscopic or polarographic techniques, a Som experience in spectroscopic or polarographic techniques, a Som
CHEMIST with general soil experience, and a SoIL CHEMIST with some CHEMIST with general soil experience, and a SOIL CHEMIST with some Wellington-The Office of the High Commissioner for New Zealand, 415 Strand, London, W.C.2 (August 1).

415 Strand, London, W.C.2 (August 1). JUNIOR PHYSICO-CHEMIST for bacteriological and virus research
work-The Secretary, Inoculation Department, St. Mary's Hospital, work-The Secretary, Inoculation De
Paddington, London, W.2 (August 1). Paddington, London, W.2 (August 1).
Assistant LECTURER IN THE DEPARTMENT OF EMBRYologXAsSistaNT LECTURER IN THE DEPARTMENT OF EMBRYOLOGX-
The Secretary, University College London, Gower Street, London, W.C.1 (August 1).

SENIOR RESEARCH OFFICERS (2), RESEARCH OFFICERS (12), ASSISTANT RESEARCH OFFTCERS (6), and RESEARCH ASSISTANTS (7), in the Ministry of Town and Country Planning-The Secretary, Ministry of Town and

STATISTICIAN-The Registrar, College of Aeronautics, Cranfleld, Bletchley, Bucks.

GAME RANGER (with a science degree, preferably in zoology) in Tanganyika Territory-The Director of Recruitment (Colonial Service), Colonial Office, 15 Victoria Street, London, S.W.1.

RESEARCH STUDENT IN SOIL SCIENCE-The Secretary, Macaulay nstitute for Soil Research, Craigiebuckler, Aberdeen.

LIBRARIAN-The Assistant Secretary, Royal Anthropological Institute, 21 Bedford Square, London, W.C.1.

LECTORER (Grade III) IN THE DEPARTMENT OF CHEMISTRY-The Clerk, Birkbeck College, Breams Buildings, London, E.C.4.

RESEARCH CHEMIST-The Director, Motor Industry Research Association, Great West Road, Brentford, Middx.

DIRECTOR OF RESEAROH-The Chairman, British Welding Research Association, 29 Park Crescent, London, W.1, endorsed 'Director'. RESEARCH ENGINEER for research on machinery used in the clay industry-The Director of Research, British Pottery Research Association, Queens Road, Penkhull, Stoke-on-Trent.

TECHNICIAN FOR BIOCHEMICAL DEPARTMENT-The Bursar, The University, Sheffield 10.

SENIOR ASSISTANT, and a LECTURER, IN THE DEPARTMENT OF EIECTRICAL ENGINEERING-The Clerk to the Governors, Woolwich

Polytechnic, Woolwich, London, S.E.18.
ILCTURER IN TELECOMMUNIOATIONS, with specialist knowledge in Radio Engineering-The Principal, Wimbledon Technical College, Gladstone Road, London, S.W.19.

\section{REPORTS and other PUBLICATIONS}

(not included in the monthly Books Supplement)

\section{Great Britain and Ireland}

Gazetteer of Great Britain: giving the Position of Towns and Important Villages shown on Ordnance Survey Maps in terms of the National Grid. Pp. 54. (Chessington, Surrey: Ordnance Survey,
[231 1946.) 5s.
Alkali \&c. Works Regulation Act, 1906, and Alkali \&c. Works Alkali \&c. Works Regulation Act, 1906, and Alkali \&c. Works
Orders 1928-1939: Eighty-second Annual Report on Alkali \&c. Works. By the Chief Inspectors. Proceedings during the Years 1939-1945 inclusive. Pp. 48. (London : H.M. Stationery Offlee, 1947.)
[291 